\title{
El ensayo a la búsqueda de la imagen
}

\section{Escales, Vanina}

Resumen:

Puede trazarse una continuidad entre la escritura del ensayo y el ensayo en su realización cinematográfica. En este trabajo trato de encontrar las invariantes de uno y su extrapolación en el otro. A lo largo de ambos, la escritura textual y la audiovisual avanzan en la búsqueda de la verdad, en otras palabras la obra de arte descubre en un acontecer una verdad ontológica a través del lenguaje o de un sistema de signos.

Palabras clave: ensayo - ensayo cinematográfico - imagen - verdad género.

(*) Ensayista, investigadora y periodista (Universidad de Buenos

Cuadernos del Centro de Estudios de Diseño y Comunicación № 61

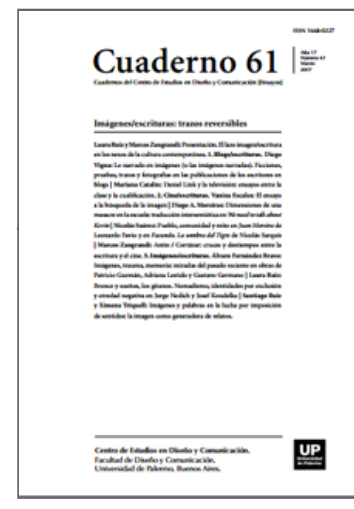

ISSN: 1668-0227

Imágenes/escrituras:

trazos reversibles

Año XVII, Marzo 2017, Buenos Aires, Argentina | 176 páginas

Ver todos los libros de la publicación

compartir en Facebook

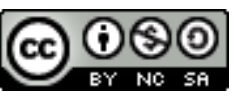

Esta obra está bajo una Licencia Creative Commons Atribución-NoComercialCompartirlgual 4.0 Internacional

Aires). Escribió la biografía de la

filósofa Lou Andreas-Salomé La seducción de la inteligencia (2008) y realizó las antologías Desobediencia civil y otros textos de Henry David Thoreau (2009) y Crónicas del Centenario de Juan José de Soiza Reilly (2008). Prologó Libertarias en América del Sur. De la A a la Z, un diccionario enciclopédico de mujeres anarquistas realizado por Cristina Guzzo. Se desempeña, además, como periodista y crítica cultural en distintos medios.

"Pienso en un mundo en el que cada memoria podría crear su propia leyenda" (Chris Marker) El ensayo como forma interesó a importantes teóricos y críticos literarios. György Lukács le dedicó sus reflexiones en la carta a Leo Popper -octubre de 1910-, publicada luego como "Sobre la esencia y forma del ensayo". Theodor W. Adorno, en la década de 1960, tomó ese escrito y repensó el género. El ensayo carga con dos grandes fuerzas: de un lado el arte y del otro la verdad a la que se llega a través de conceptos. En esa zona liminar, callejuela sin señales, el ensayo avanza sin preguntarse por el problema de la representación.

Su aspiración a la verdad no priva a esa búsqueda de un lenguaje liberado de las ataduras técnicas. Placer verbal donde suena la verdad. 
La preocupación de Lukács es si los escritos de este tipo constituyen una forma y "en qué medida le comunican la capacidad de una nueva reordenación conceptual de la vida" (Lukács, 1975, p. 15). Las formas literarias no son simples hechos artísticos sino que en ellos podemos reconocer las posibilidades de nuestra vida. Lukács lo escribe de este modo en "Metafísica de la tragedia" (1975): La forma es el juez supremo de nuestra vida. El poder dar forma es una fuerza juzgadora, algo ético, y en toda configuración está contenido un juicio de valor. Todo tipo de dación de forma, toda forma de literatura es un estadio en la jerarquía de las posibilidades de vida: la palabra que todo lo decide sobre un hombre y su destino queda dicha en cuanto que se determina qué forma soportan sus manifestaciones de vida y qué puntos culminantes existen.

(Lukács, 1975, p. 272) Nuestra vida es un esfuerzo por lograr tallar una forma, por eso la forma es algo ético, toma de nuestra vida en el momento en que es voluntad.

El ensayista interroga el mundo desde su ser ahí. El hilo que lo une a su objeto es el extrañamiento, que lo deslumbra como si fuera un etólogo de lo humano. Ronda el objeto, le da vueltas, lo desarma, lo toca, lo comprende y, por fin, lo vuelve a componer. El final importa pero no más que el recorrido; en cada escena, al igual que en cada deriva por la que nos llevó el pensamiento, encontramos la inmanencia misma del goce. Una vez que llega al final, el tema que nos ocupó y que creemos agotado para nosotros, recibe un punto. El ensayo como forma, sin embargo, se abrirá paso a través de nuevas excusas, nuevos objetos y otros escritos. Porque su tema mismo, en el fondo, es la vida. Construye conceptos intuyendo y deteniéndose en lo que las palabras encierran; siempre pregunta por el presente de la vida, aunque escriba sobre los orígenes de la filosofía o los mapas estelares: inquiere la contemporaneidad.

El ensayo es un género artístico volcado a la verdad. Pero es necesario subrayar la diferencia con el arte. Lukács: "el ensayo se enfrenta con la vida con el mismo gesto que la obra de arte, no solo con el gesto; lo soberano de esa actitud puede ser lo mismo, pero aparte de eso no hay ningún contacto entre ellos" (1975, p. 38). ¿Cuál es la verdad del ensayo cinematográfico? Hace evidente el recorrido por los conceptos cuando camina junto a la duda y el error sin ocultarlos. Es en las correcciones y en las vacilaciones donde las preguntas comienzan a despejarse. "El ensayo piensa junto en libertad lo que libre y junto se encuentra en el objeto elegido", dirá Adorno (1962, p. 21). Es un género liberado de metafísica, no buscará orígenes, fundamentos, ideales ni duplicidades. Al mismo tiempo es una escritura que avanza en las ideas, que van cobrando forma, dibujándose palabra a palabra sobre el teclado o el cuaderno.

El ensayo cinematográfico nos presenta desafíos a la hora de pensarlo ya que conserva del otro esa disputa genérica. Con una sección dentro de los subgéneros del documental en los festivales de cine, no está probado su parentesco con los documentales. No intenta explicar verdades universales, ni conocer temáticas determinadas, ni contar una hazaña, vida u obra de personajes ilustres o desconocidos. Más bien, no hay una voz de autoridad que medie con el objeto. El tiempo de la narración responde a las formas en que las reflexiones fluyen y no a un tiempo cronológico símil al del mundo material. Podríamos decir que el ensayo cinematográfico muestra el desarrollo de una idea. Casualidad o no, siempre se muestra el dispositivo cinematográfico: no la "realidad" sino la textura del celuloide, la cámara, ninguna de las convenciones para construir "lo real" sino una persona mirando a cámara, el sonido en primer plano de una imagen borrosa y lejana. Liberado del esfuerzo que demanda el realismo del documental, el ensayo cinematográfico no coloca las convenciones a observar por la lente de la cámara sino que coloca al cineasta como creador de imágenes. 
Me pregunto si el ensayo audiovisual imita a la poesía o si es él mismo poesía por otros medios.

El film Sans soleil (1983), de Chris Marker comienza con la voz en off de una mujer que dice "[placa negra] La primera imagen de la que me habló fue la de tres niños en un camino, en Islandia, en 1965. [imagen de los niños] [placa negra] Me decía que para él era la imagen de la felicidad, y también que había intentado en numerosas ocasiones asociarla con otras imágenes [aviones militares], [placa negra, otra vez] pero que nunca había funcionado.

Me escribió: '...un día la pondré sola al comienzo de una película, con un largo comienzo negro. Si no se ve la felicidad en esta imagen, al menos se verá la oscuridad'”.

La palabra aparece en esta obertura cuando la imagen desaparece. Hay imágenes que bastarían para capturar un sentido, el de la felicidad, en este caso. La tercera persona de esa voz reafirma las marcas exteriores de una narración convencionalmente ficcional. Recurso estético, en la composición de palabra e imagen, Sans Soleil va armando un poema.

Marker, a lo largo de su obra fílmica, también va haciendo filosofía y de su teatro filosófico participan los signos que más definen los siglos XX y XXI: las imágenes del audiovisual. La idea del teatro filosófico para pensar la historia de la filosofía se la debemos a Gilles Deleuze (2002, p. 34): se trata de pensar un espacio escénico vacío que se va llenando de signos y máscaras y representaciones particulares. ¿Cuáles son los signos de Marker? Las risas de juegos televisivos, el fetiche del dinero, las botas de militares, la imaginación tecnológica en los despegues de cohetes al espacio, la chatarra como detritus de la cultura y restos de la moda, las revueltas populares, los cuerpos liberados de los órdenes estatales. ¿Con qué imagen será recordado el siglo pasado? Marker debe de haberse hecho esa pregunta. La pregunta por la imagen es una pregunta por la memoria.

Dice Christa Blümlinger: En el ensayo fílmico se trata siempre de una pregunta sobre la fuente de lo enunciado. En cuanto un texto ensayístico piensa su modo de enunciación sobrepasa esta separación del pensamiento en el "sí mismo" y el "otro": las posiciones se diluyen al condicionarse recíprocamente. Al transmitirse la representación de la realidad social a través de la subjetividad, ésta se convierte en su expresión. La reflexión sobre uno mismo es la condición para las consideraciones del ensayista sobre el mundo". (2007, p. 54-55) La poesía y el ensayo cinematográfico tienen una relación de continuidad con la verdad.

Para decirlo con precisión, la obra de arte descubre en un acontecer cierta verdad ontológica a través del lenguaje o de un sistema de signos. La pregunta que atraviesa distintos filmes de Chris Marker es por la memoria, desde Sans Soleil a December Seeds (2009), Le Fond de l'air est rouge (1977), Si j'avais quatre dromadaires (1966), Chats perchés (2004) (Imagen 1), Lettre de Sibérie (1957), Junkiopia (1981) y Les Statues meurent aussi (1953).

La preocupación por la memoria es un asunto contemporáneo, la abundancia de datos e información la asfixian hasta arrinconarla en el olvido. Y no solo eso: el cotidiano banal moderno que clausura o evita la experiencia vital, sino que a la reflexión sobre la memoria el olvido contesta erigiendo museos -una forma de olvidar, cristalizando-. Si en la experiencia confluye la subjetividad individual y el lenguaje de la cultura compartida, la pobreza de la experiencia (Benjamin, 1982) nos deja en la desesperación del vacío de la transmisión. ¿Qué 
recordaremos de esta contemporaneidad anémica, qué imágenes nos llevarán al ensueño como si fueran el sabor de una madalena? Escribe Jacques Rancière sobre Le tombeau d'Alexandre (Marker, 1992) que: Lo olvidado, lo negado o lo ignorado que las ficciones de la memoria pretenden testimoniar se opone a esa "realidad de la ficción" que asegura el reconocimiento como en un espejo entre los espectadores de la sala y las figuras de la pantalla, entre las figuras de la pantalla y las del imaginario social. En contra de esa tendencia a reducir la invención ficcional a los estereotipos del imaginario social, la ficción de la memoria se instala en el hueco que separa la construcción del sentido, lo real referencial y la heterogeneidad de sus "documentos". (Rancière, 2005,p. 183) Es la tentación por buscar invariantes que me lleva a preguntar si todo ensayo documental lleva en sí la crítica del espectador, esa suerte de sujeto visor que premia con su presencia cada vez más un realismo que lo confirma. Y, también, ya no como intriga sino como afirmación, estamos ante un tipo de cine autorreferencial, que reflexiona sobre sí mismo al tiempo que lo hace sobre su objeto. Renuncia a repetir los clichés tanto de la "realidad de la ficción" como de la gramática trillada del documental clásico: entrevista a personaje, corte, voz en off sobre imágenes de archivo, corte, y así hasta la desazón final. Tanto en Santiago (Uma reflexão sobre o material bruto) (Moreira Salles, 2006) como en Jallalla Bolivia (Fidalgo, 2007) se hacen ingresar imágenes bastardas que el cine suele dejar afuera del montaje. Son bienvenidos los fantasmas de la cámara, el grano, el fuera de campo que el productor comercial desprecia. Sans Soleil (Imagen 2):

"Francamente, ¿alguien ha inventado algo más estúpido que decirle a la gente, como se enseña en las escuelas de cine, que no miren a la cámara?" Hay mucho para explorar en este cine sobre la relación entre espectador, imagen y política; entre arte y política; y sobre el rol del artista-cineasta-ensayista. Dijimos que es un cine que inquiere la contemporaneidad; en otras palabras intenta entender la época, atraparla mientras el tiempo fuga los signos que le dan pulso. Incomoda, por lo tanto; la verdad nunca ha sido popular. Y por otra parte está jaqueado por una paradoja: Uno atraviesa una época igual que el puente de la Dogana, es decir, más bien rápido. Primero, no se la mira mientras viene. Y después, al llegar a su altura la descubrimos, y deberemos convenir que así fue construida, y no de otro modo. Pero ya doblamos este cabo, y lo dejamos atrás, y avanzamos hacia aguas desconocidas. (Debord, 1978, p. 48) Pero ¿qué otra cosa hacer? Un susurro como bajo continuo. Lo importante es qué hizo el artista con su época.

La vulgaridad del sí de los poderes está ausente del ensayo. December Seeds (Marker, 2009) deconstruye imágenes y, a través de ellas, vive la revolución espiritual de los disturbios griegos de finales de 2008. En su política menos evidente, este cine anula el poder cuando responde con imágenes fuera de toda posibilidad de captura, cuando pervierte el ritmo y el tiempo del cine, cuando desacopla formas de mirar, cuando es amenaza del cine sincronizado al statu quo. "Esta vida y este cine son ambos poca cosa; y es en esto que son indistintamente intercambiables", se escucha a los pocos minutos de comenzar In girum imus nocte et consumimur igni (Debord, 1999, p. 5-6) (Imagen 3).

La película del director rosarino Diego Fidalgo, Jallalla Bolivia, es una extrañeza dentro de la producción nacional. Tierra de los padres (Prividera, 2012), La televisión y yo (Di Tella, 2003), Las aguas del olvido (Perel, 2013) podrían pensarse como ensayos, también.

En el caso de Brasil, São Paulo: Sinfonia e Cacofonia (Jean-Claude Bernardet, 1995) es una excepcional radiografía de la ciudad a partir del montaje de más de cien filmes brasileños.

La experiencia trunca, odiosa pero magnética de la vida en una ciudad descomunal, se muestra a través de la construcción que el mismo cine hizo de ella. Y la ya nombrada Santiago (Uma reflexão sobre o material bruto). 
¿La cámara rodando puede captar el momento de epifanía en donde la verdad se encuentra con la toma exacta? La historia del cine puede ser la tenacidad de esa creencia. Lo que el espectador ve en la película de Salles es el modo de funcionamiento del artificio operando sobre el material fáctico y algo no menor: el relato, durante el mismo devenir de la realización, sobre la conversión del cineasta por su objeto y sobre el acercamiento ético al objeto a retratar.

Una hipótesis para futuros escritos es volver a mirar, con estas teorías de nuestro lado, películas del cine experimental de la década de 1960.

En Jallalla Bolivia lo primero que aparece es el material fílmico, el artificio cinematográfico: las imágenes y el sonido marcados por la toma de una vieja cámara Bolex a cuerda en donde lo brumoso comienza a aclarar y, en blanco y negro, vemos a personas que van cruzando a pie el límite con Bolivia. La música incidental es perturbadora. En Jallalla Bolivia (Imagen 4) no hay voz en off, no hay autoridad, no hay entrevistados, la cámara renuncia a interpretar. Y nada de esto es necesario para entender lo que significó la asunción de Evo Morales por primera vez a la presidencia de ese Estado plurinacional que es Bolivia. La música ocupa un lugar tan central porque amplifica lo que no podemos escuchar y que Diego Fidalgo intuye: el bramido agónico de la tierra, el estremecimiento de una cultura que espera hace quinientos años. Los sonidos corresponden a las composiciones de Mauricio Kagel y las músicas andina y aymara, por un lado, y las voces de la calle como ecos de la ciudad, más los noticiarios radiales, pero con una distancia de escucha: la de un extranjero que quiere comprender, abandonando lo que cree sabido. La película es un poema épico y elegíaco a la vez.

En Jallalla, la voz de Evo Morales no acompaña su imagen, ambas van desacopladas. Ese recurso que responde al cine moderno (el acto de la palabra se convierte en una imagen acústica autónoma) tiene un fundamento político: la voz de Evo ya no le pertenece, las palabras ya no son suyas. Fidalgo va jugando con el color y el blanco y negro de las imágenes.

La vitalidad del color está anclado al presente del film, el subtexto es el blanco y negro: la larga espera y el tiempo. La belleza de esta película es inagotable; encontró su forma justa (como exactitud y justicia).

Introduzco acá una nueva digresión para reconsiderar filmes como Porcile (1969) y Salò o le 120 giornate di Sodoma (1975), ambos de Pier Paolo Pasolini y las películas sugerentes y desbordantes de Terrence Malick The Tree of Life (2011) o The Thin Red Line (1998). Sobre Porcile es el propio Pasolini que da la pista cuando dice en una entrevista: En lugar de escribir un ensayo sobre el final del marxismo en Italia, sobre la crisis del marxismo en Italia a finales de los años '50, y habría podido escribirlo, yo he traducido este ensayo ideológico en términos poéticos. $Y$ he creado una parábola. Pero con esto no he querido ser didáctico, he querido plantear problemas igual que los habría planteado en un ensayo. Un ensayo escrito por mí (...) habría sido una obra problemática. Y dicha problemática, de hecho, está presente en la película, que no propone soluciones, que no enseña nada; plantea problemas, hace consideraciones, hace observaciones.

(Pasolini, 2011, p. 88) Malick no concede entrevistas. Lo que se presentó como una película bélica en The Thin Red Line era un tratado sobre las consecuencias éticas de dar muerte, de los efectos de la guerra sobre el ser humano y de la absurda batalla del hombre contra la Naturaleza. Todo lo que el humano toca queda alterado, pero una imagen da la idea de quién ganará esa batalla: las ruinas de los parques, con sus musgos que avanzan en otro tiempo. The Tree of Life se asienta sobre el trascendentalismo americano, corriente filosófica 
heredera del idealismo alemán que nació en Nueva Inglaterra. El trascendentalismo usó como sinónimos "dios", "naturaleza" o "leyes superiores". En ambas películas es la Naturaleza -y Malick probablemente sea lector de Ralph Waldo Emerson- la gran potencia creadora, donde lo humano sería uno de sus despliegues. De gran lirismo -sobre todo visual-, The Tree of Life es una plegaria que agradece la existencia y entiende su fragilidad, pero no desespera por la finitud de la vida porque la sitúa en una ecología natural, en un ciclo que comienza en el inicio de los tiempos y no tiene fin.

El ensayo cinematográfico, llamado así por su comunión con el ensayo como género literario, es el lugar del pensamiento en el cine. Los conceptos van construyéndose en lo nebuloso del proceso que va hacia esa verdad de la que antes hablábamos. Es el género que corresponde a nuestra época y el que, quizá, sea capaz de arrebatar nuestras mejores imágenes al espectáculo que hace languidecer nuestra experiencia.

Bibliografía

Adorno, T. W. (1962). "El ensayo como forma”. En Notas de literatur. Barcelona: Ariel. (1984). Teoría Estética. Barcelona: Orbis Hyspamerica.

Agamben, G. (2010). Infancia e historia. Buenos Aires: Adriana Hidalgo.

Andrade Ramos, M. (Productor) y Moreira Salles, João (Director/Escritor). (2007). Santiago (Uma reflexão sobre o material bruto) [Película]. Brasil: Videofilmes Produçoes Artisticas Ltda.

Baldi, J. V. (Productor) y Pasolini, P. P. (Director/Escritor). (1969). Porcile [Película]. Italia: I Film Dell'Orso.

Benjamin, W. (1982). Experiencia y pobreza (1933). Madrid: Taurus.

Bernardet, J.-C. (Productor/Director/Escritor). (1995). São Paulo: Sinfonia e Cacofonia [Película]. Brasil: Teatra.

Blümlinger, C. (2007). "Leer entre las imágenes". En La forma que piensa. Tentativas en torno al cine-ensayo. Navarra: Gobierno de Navarra.

Cloquet, G., Marker, C. y Resnais, A. (Directores) y Marker, C. (Escritor). (1953). Les Statues meurent aussi [Película]. Francia: Présence Africaine y Tadié Cinéma.

De Stefanis, A., Girasante, A. y Grimaldi, A. (Productores), Pasolini, P. P. (Director) y Pasolini, P. P. y Citti (Escritores). (1975). Salò o le 120 giornate di Sodoma [Película]. Italia: Produzioni Europee Associati y Les Productions Artistes Associés.

Debord, G. (1999). In girum imus nocte et consumimur igni. Barcelona: Etcétera.

Fidalgo, D. (Director/Escritor). (2007). Jallalla Bolivia [Película]. Argentina: Oxímoron Cine.

Gardner, D. y Green, S. (Productores) y Malick, T. (Director/Escritor). (2011). The Tree of Life [Película]. Estados Unidos: River Road Entertainment y Plan B Entertainment. 
Geisler, R., Hill, G. y Roberdeau, J. (Productores) y Malick, T. (Director/Escritor). (1998). The Thin Red Line [Película]. Estados Unidos: 20th Century Fox.

Guarini, C. y Céspedes M. (Productores), Di Tella, A. (Director) y Di Tella, A y Di Tella, R. (Escritores). (2003). La televisión y yo [Película]. Argentina: Cine Ojo.

Lukács, G. (1975). El alma y las formas. Teoría de la novela. México: Grijalbo.

Marker, C. (Director). (1983). Sans soleil [Película]. Francia: Argos Films.

Marker, C. (Director/Escritor). (1957). Lettre de Sibérie [Película]. Francia: Argos Films.

Marker, C. (Director/Escritor). (1966). Si j'avais quatre dromadaires [Película]. Francia: Iskra.

Marker, C. (Director/Escritor). (1977). Le Fond de l'air est rouge [Película]. Francia: Dovidis.

Marker, C. (Director/Escritor). (1981). Junkiopia [Película]. Francia: Argos Films y Janus Films.

Marker, C. (Director/Escritor). (1992). Le tombeau d'Alexandre [Película]. Francia: Les Films de l'Astrophore y La Sept.

Marker, C. (Director/Escritor). (2004). Chats perchés [Película]. Francia: Les Films du Jeudi.

Marker, C. y Panagyotis Karagiorgas (Directores). (2009). December Seeds [Película]. Grecia.

Pasolini, P. P. (2011). Nueva York. Madrid: Errata Naturae.

Perel, J. (Director/Escritor). (2013). Las aguas del olvido [Película]. Argentina.

Rancière, J. (2005). La fábula cinematográfica. Madrid: Paidós.

Ratto, P. (Productor) y Prividera, Nicolás (Director/Escritor). (2012). Tierra de los padres [Película]. Argentina: Trivial Media.

Abstract:

It is possible to find continuity between essay genre and film essay (or cinematic essay). In this paper I try to find the insistence of the writing genre and the extrapolation on the other. Throughout both, the textual and the audiovisual essays advance in the search for truth; in other words: in any occurrence, the artwork can discover an ontological truth through language or a system of signs.

Key words:

essay - film essay - truth - image - genre.

Resumo: 
É possível traçar uma continuidade entre a redação do ensaio e o ensaio em sua realização cinematográfica.

Este trabalho deseja encontrar as invariáveis da produção escrita e a sua extrapolação na produção audiovisual. Ao longo das duas criações, a produção textual e a audiovisual avançam em busca da verdade, em outras palavras, a obra de arte descobre na sequencia a verdade ontológica através da linguagem ou de um sistema de signos.

Palavras chave: ensaio - ensaio cinematográfico - imagem - verdade - gênero.

El ensayo a la búsqueda de la imagen fue publicado de la página 51 a página58 en Cuadernos del Centro de Estudios de Diseño y Comunicación № 61 